\title{
Partial Lipodystrophy and Dermatomyositis
}

\author{
Antonio Torrelo, MD; Agustín España, MD; Pablo Boixeda, MD; Antonio Ledo, MD \\ Department of Dermatology \\ Hospital "Ramón y Cajal" \\ Apartado 37. 28034-Madrid, Spain
}

Partial lipodystrophy (PL) is characterized by a slow and symmetrical loss of subcutaneous fatty tissue, mainly involving the upper half of the body. We report a case of PL associated with dermatomyositis.

\section{REPORT OF A CASE}

In 1978, an 11-year-old boy began to notice proximal weakness in his limbs together with facial erythema; palpebral violaceous edema; and erythematous papules on his elbows, knees, and over the metacarpophalangeal joints. A diagnosis of polymyositis/dermatomyositis was made. He was treated with oral prednisone, which caused the symptoms to disappear promptly. In 1980, proximal weakness, dysphagia, clyspnea, and similar cutaneous lesions once again developed. Muscular wasting and slight articular retractions were evident. Laboratory values at that time showed the following values or results: aspartate aminotransferase, $122 \mathrm{U} / \mathrm{L}$ (normal, 0 to $40 \mathrm{U} / \mathrm{L}$ ); alanine aminotransferase, $140 \mathrm{U} / \mathrm{L}$ (normal, 0 to $40 \mathrm{U} / \mathrm{L}$ ); creatine phosphokinase, 303 $\mathrm{U} / \mathrm{L}$ (normal, 0 to $200 \mathrm{U} / \mathrm{L}$ ); aldolase, $2.5 \mathrm{U} / \mathrm{L}$ (normal, 0.8 to $1.9 \mathrm{U} / \mathrm{L}$ ); lactic dehydrogenase, greater than $1500 \mathrm{U} / \mathrm{L}$ (normal, 230 to $460 \mathrm{U} / \mathrm{L}$ ); creatinine clearance, $55 \mathrm{~mL} / \mathrm{min}$ (normal, 88 to $120 \mathrm{~mL} / \mathrm{min}$ ); antinuclear antibodies, positive at $1 / 320$ with a homogeneous pattern; anti-DNA, anti-Sjögren syndrome A, anti-Sjögren syndrome $\mathrm{B}$, and anti-ribonucleoprotein antibodies, negative; $\mathrm{C} 3$ and $\mathrm{C} 4$, normal; $\mathrm{CH}_{50}$, normal; circulating immune complexes, not detectable by the Raji cell test; and serology to Toxoplasma, negative.

Results from the electromyogram and the findings from the muscular biopsy specimen were typical of polymyositis. The patient was sent to our department for treatment and follow-up. He received a course of oral prednisone and azathioprine, which controlled the disease. Moreover, on clinical examination, we found a loss of buccal fat, the eyes were deep set, and numerous fine rhytids appeared when the patient smiled. Although muscular waste was evident, he had a pseudohypertrophic appearance. The superficial veins were patent (Figure). These changes were present in the upper half of his body, while no abnormalities were present in the lower half. A deep-skin biopsy specimen from the patient's left arm showed a complete absence of subcutaneous and periadnexal fatty tissue. The patient could not ascertain with accuracy when these changes began, and he thought they were present from early childhood. No familial records were available. He has undergone follow-up in our department, and, on the last visit, in 1990, no changes had appeared. All throughout this period, complement levels, renal function studies, glycemia, urinalysis, and C3 nephritic factor determinations have been normal or negative. 


\section{COMMENT}

Multiple, patchy, nonsymmetrical lesions typical of localized lipoatrophy have been reported together with dermatomyositis ${ }^{1}$ and also myositis and muscular atrophy. ${ }^{2}$ Localized lipoatrophy may represent an end stage of panniculitis. ${ }^{3}$ Thus, although panniculitis is rare in dermatomyositis, ${ }^{1}$ it may account for localized lipoatrophy. In contrast, our patient represents the first case reported of dermatomyositis and PL.

The pathogenesis of PL is unknown. Its association with gate disorders such as Sjögren's syndrome, lupus erythematosus, and autoimmune thyroid disease suggests an immunologic basis. ${ }^{4}$ In addition, some patients have mesangiocapillary glomerulonephritis, C3 hypocomplementemia, and the presence of C3 nephritic factor. A role for circulating immune complexes has been proposed for this association. ${ }^{4}$ On the other hand, other authors explain PL on a neurologic or endocrinologic basis. ${ }^{4}$ Pathogenesis of dermatomyositis is equally unknown, but immunologic disturbances such as circulating autoantibodies and immune complexes may be strongly involved. ${ }^{5}$

Although we cannot state that the association of PL and dermatomyositis is accidental, the immunologic background of both diseases may point to some common pathogenetic mechanisms.

\section{REFERENCES}

1) Commens C, O'Neill P, Walker G. Dermatomyositis associated with multifocal lipoatrophy. J Am Acad Dermatol. 1990; 22: 966-969.

2) Palliyath S, Garcia CA. Multifocal interstitial myositis associated with localized lipoatrophy: a benign course. Arch Neurol. 1982; 39: 722-724.

3) Peters MS, Winkelmann RIF. Localized lipoatrophy (atrophic connective tissue disease panniculitis). Arch Dermatol. 1980; 116: 1363-1368.

4) Font J, Herrero C, Bosch X, Cervera R, Ingelmo M, Mascará JM. Systemic lupus erythematosus in a patient with partial lipodystrophy. J Am Acad Dermatol. 1990; 22: 337-340.

5) Rowell NR. Lupus erythematosus, scleroderma and dermatomyositis. The "collagen" or "connective tissue" diseases. In: Rook A, Wilkinson DS, Ebling FJG, Champion RH, Burton JL, eds. Textbook of Dermatology. Boston, Mass: Blackwell Scientific Publications Inc; 1986: 1281-1392. 


$$
1
$$

